\title{
Rantai Pasar Komoditas Pertanian dan Dampaknya Terhadap Kegiatan Perdagangan Komoditas Pertanian Pasar Projo
}

\author{
Erwin Kharisma ${ }^{1}$ \\ PT Nutrifood Indonesia \\ Balikpapan, Indonesia
}

\begin{abstract}
Subdistrict Ambarawa as a small town in Central Java is a city that has the potential in the domestic and regional services. Projo market located in downtown Ambarawa is one of the largest traditional market in Semarang Regency. Projo market is a market first that held a special morning vegetable market. Intensive activity often cause traffic jams in front of the Market Projo passed by the national road-Jogjakart Semarang. Ambarawa position is located in the middle of agricultural areas have specialized functions makes Ambarawa make Ambarawa be the exit for agricultural commodities. To find the perpetrator, the location, flow and value-added agricultural commodities in the market Projo, it is necessary to review how the chain of agricultural commodity markets in the Market Projo.Market chain analysis will address how the role of Market Projo Ambarawa particularly in the area of the system especially agricultural commodities. From the analysis of the market chain will be known to impact the flow Projo Market chain of agricultural commodities trading activities. Is the impact of the market chain with trading activities have positive and negative for the traders in the Market Projo. This study aims to determine the condition of the agricultural commodity market chain and its relation to the activities of trade in agricultural commodities in the market Projo, Ambarawa. This research approach is qualitative penedekatan with descriptive statistical analysis techniques. Under the conditions of the market chain will be described the relationship between market chain of agricultural commodities trading activities Projo Market. The results of the analysis it is associated chain actors vegetables and fruits were not only from local actors, but also there are actors nonlocal located near the center producing commodities, such as the perpetrator of farmers and gatherers. While the majority of local actors are actors who sell at the Market Projo such as market traders and retailers. With the presence of nonlocal actors illustrates that commodity in a commodity market Projo nonlocal. Nonlocal vegetables are from Sub Getasan and District Ngablak. Then for for commodities originating from the center of fruit like Batu in East Java, Malang, Banyuwangi, and Kediri, while for centers such as Magelang, Central Java and Kebumen.For the analysis of the chain, most players in this industry sector is taking the basic ingredients of vegetables and fruits to be processed into other forms, such as food, vegetables, fruit soups, fruit ice. The perpetrator was a perpetrator of restaurants and pkl.For added value, some local actors such as market traders, retailers, and collectors get the added value is large enough compared to other actors of vegetables, local fruits, and fruit imports. Only farmers who obtain the greatest added value of vegetables, fruit for local and imported commodities of local actors such as collectors and market traders get the most added value than nonlocal actors involved. From the above descriptions can be drawn with the impact of the market chain of agricultural commodities trading activities in the Projo Market terfasilitasinya local merchants to sell at the market and value-added Projo received from local traders is quite big
\end{abstract}

\footnotetext{
${ }^{1}$ Korespondensi Penulis: PT Nutrifood Indonesia, Balikpapan Email: erwinkharisma@gmail.com
} 


\section{Rantai Pasar Komoditas Pertanian dan Dampaknya Terhadap Kegiatan Perdagangan Komoditas Pertanian}

compared to nonlocal actors commodity chain of vegetables and fruits. With local traders in the Market terfasilitasinya Projo, it is necessary to the arrangement and the addition of market capacity because the capacity exceeds the capacity of market traders, especially the morning market. Projo market as needed to absorb the local market traders and local people's income will rise gradually to Market Projo can benefit the surrounding community.

Kata Kunci: Projo market, the market Chain Analysis, Agricultural Commodity Chain

\section{Pendahuluan}

Rantai pasar merupakan sebuah rantai yang digunakanuntuk menggambarkan sejumlah jaringan yang menghubungkan semua pelaku terkait dan transaksi yang terjadi dalam pergerakan barang pertanian dari pertanian ke konsumen (Lundy.et al, 2004:15). Tujuan dari rantai pasar adalah untuk mendapatkan lebih rinci pemahaman tentang aktor, kegiatan, biaya, dan peluang terkait dengan aliran produk tertentu dan terkait layanan, dimulai dengan petani dan berakhir dengan pembeli yang ditargetkan atau konsumen Informasi diperoleh melalui analisis rantai pasar juga membantu dalam mengidentifikasi rantai pasar terbaik untuk klien tertentu dan lokasi kunci pelaku rantai pasar yang akan membeli produk (Lundy.et al, 2004:17).Dalam analisis rantai pasar komoditas pertanian, didalamnya terdapat analisis harga dan penambahan nilai dari urutan kegiatan yang lengkap mulai dari bahan baku hingga proses akhir sampai ke konsumen, sekaligus menunjukkan keseluruhan para pelaku dan kegiatan yang relevan yang memberikan pengaruh langsung dalam penentuan produk akhir (Tallec dan Bockel, 2005:4).

Dalam hal ini analisis rantai pasar komoditas pertanian dapat dilakukan di pasar tradisional sebagai salah satu pemasok komoditas pertanian. Pasar tradisional sebagai potensi lokal sering digunakan oleh penduduk untuk memasarkan produk pertaniannya, seperti buah-buahan, sayuran, dan tanaman perkebunan. Hal ini sudah menjadi umum karena setiap pasar tradisional di Indonesia menjual produk pertanian. Pasar sendiri merupakan suatu sistem yang menghasillkan peraturan harga-harga dengan sendirinya. Penyampaian barang dari produsen (petani) ke pedagang dan ke konsumen akhir inilah yang menjadi dasar untuk melakukan analisis rantai pasar komoditas pertanian di pasar tradisional. Pasar tradisional yang dijadikan objek dalam penelitian ini adalah Pasar Projo. Pasar Projo yang terletak di Kecamatan Ambarawa merupakan salah satu pasar tradisional terbesar di Kabupaten Semarang. Pasar Projo merupakan pasar lengkap dengan menjual barang sehari-hari dari komoditas pertanian, makanan hingga sandang. Aktivitasnya yang padat sering menimbulkan kemacetan di depan Pasar Projo yang dilewati oleh jalan nasional Semarang-Jogjakarta. Padatnya aktivitas tidak lepas dari posisi Ambarawa yang strategis. Dengan letaknya yang strategis, merupakan potensi bagi Ambarawa khususnya Pasar Projo dalam hal pelayanan bagi wilayah sekitarnya.

Kecamatan Ambarawa sebagai kota kecil di Jawa Tengah merupakan kota yang mempunyai potensi dalam pelayanan domestik maupun regional. Hal ini dapat dilihat dari letak Ambarawa yang strategis dalam sistem perkotaan di Jawa Tengah. Menurut Isti Andini (2006:41), peran Ambarawa dalam wilayah sudah dijabarkan dalam RTRW Propinsi Jawa Tengah tahun 2002. Posisi Ungaran-Bawen- Ambarawa dalam wilayah dilihat sebagai fungsi dalam sistem perkotaan Jawa Tengah dan menyandang fungsi sebagai pusat kegiatan wilayah dengan wilayah pelayanan melingkupi Kabupaten Semarang, Kabupaten Kendal, Kabupaten Demak, dan Kabupaten Purwodadi. Hal ini menjelaskan bahwa Ambarawa memliki potensi dalam pusat pelayanan regional Jawa Tengah bersamaan dengan Bawen dan Ungaran. Kemudian dari aspek pertumbuhan kota, jalur transportasi memegang porsi besar pada perkembangan kota, artinya Kabupaten Semarang yang dilewati jalur regional dari pusat pertumbuhan Kota Semarang dan Solo yaitu Ungaran - 
Bawen - Ambarawa memiliki pertumbuhan yang signifikan. Selain aspek transportasi, aspek lokasi juga berpengaruh pada pertumbuhan kota. Hal ini dapat dilihat dari perbedaan kecepatan pertumbuhan antara kota- kota di Kabupaten Semarang dengan kota-kota di Kabupaten Kendal dan Demak yang memiliki akses yang sama besar terhadap jalur transportasi regional dan letak yang sama berimpit batas dengan Kota Semarang (Andini, 2006:51).

Pada aspek hirarki kota, Ambarawa dalam koridor sistem perkotaan SemarangSurakarta, Ambarawa termasuk orde II yang merupakan sub sistem dari Kota Semarang yang memiliki orde tertinggidi koridor ini. Orde II disini artinya adalah kelompok kota dengan kemampuan pelayanan pada subsistem perkotaan pada koridor yang harus memiliki paling tidak tiga dari fasilitas-fasilitas berikut; bank/lembaga keuangan, kantor bupati/walikota, pelabuhan, bioskop, akademi/perguruan tinggi dan rumah sakit. Pada aspek ekonomi, khususnya Ambarawa yang dilewati jalur regional mempunyai spesialisasi fungsi yang terletak ditengah kawasan produksi pertanian menjadikan Ambarawa pintu keluar bagi komoditas pertanian. Ambarawa yang diapit oleh Kecamatan Bandungan, Jambu, Sumowono, dan bawen, dimana keempat kecamatan tersebut merupakan sentra pertanian, perkebunan, tanaman pangan, peternakan, dan perikanan. Sehingga Ambarawa yang mempunyai keuntungan lokasi sering dimanfaatkan oleh kecamatan lain untuk memasarkan komoditas mereka karena kedekatannya dengan jalur regional (Andini, 2006:70).

Dari penjelasan di atas, potensi Ambarawa dari aspek-aspek diatas mengambarkan bahwa pertumbuhan Ambarawa didasarkan pada peran yang besar dalam wilayah, khususnya koridor sistem perkotaan Semarang-Surakarta. Seperti uraian di atas, dari aspek ekonomi, Ambarawa mempunyai spesialisasi fungsi yang terletak ditengah kawasan produksi pertanian menjadikan Ambarawa pintu keluar bagi komoditas pertanian. Dengan letak yang strategis yaitu berada di jalur regional, aktivitas di Pasar Projo sering menimbulkan kemacetan di jam-jam sibuk. Hal inilah yang menyebabkan proyek pembangunan jalan lingkar Ambarawa yang masih dalam tahap pembangunan, diharapkan dapat mengantisipasi kemacetan yang terjadi di depan jalan Pasar Projo tersebut.

Seperti yang penjelasan di atas, untuk mengidentifikasi aktivitas di Pasar Projo adalah dengan menggunakan analisis rantai pasar. Analisis rantai pasar merupakan penggambaran sebuah rantai yang digunakan untuk mendeksripsikan sejumlah jaringan yang menghubungkan semua pelaku terkait dan transaksi yang terjadi dalam pergerakan barang pertanian dari pertanian ke konsumen (Lundy.et al, 2004:15). Berdasarkan uraian di atas, Pasar Projo sebagai pusat transaksi di Ambarawa, mempunyai peran yang besar dalam perwilayahan. Untuk mengetahui pelaku, lokasi, aliran dan nilai tambah komoditas pertanian di Pasar Projo, maka perlu dikaji bagaimana rantai pasar komoditas pertanian di Pasar Projo dan dampaknya terhadap kegiatan perdagangan komoditas pertanian. Dari kondisi rantai pasar tersebut akan dapat digambarkan dampak rantai pasar Pasar Projo terhadap kegiatan perdagangan komoditas pertanian. Peran tersebut dapat berdampak positif atau negatif bagi pedagang di Pasar Projo. Karena seperti yang disebutkan di atas, Ambarawa mempunyai spesialisasi fungsi yang terletak ditengah kawasan produksi pertanian menjadikan Ambarawa sebagai pintu keluar bagi komoditas pertanian. Dengan spesialisasi fungsi tersebut, dampaknya adalah banyaknya pedagang lokal yang memanfaatkan potensi Ambarawa untuk memasarkan komoditas pertanian.

\section{Rumusan Masalah}

Pasar Projo merupakan pasar strategis yang memasarkan komoditas pertanian dengan keuntungan lokasi yang strategis yang berada di pusat Kota Ambarawa. Keberadaan Pasar 
Projo merupakan spesialisasi fungsi yang terletak ditengah kawasan produksi pertanian menjadikan Pasar Projo pintu keluar bagi komoditas pertanian. Namun, sebagai pemasok dan pelayanan komoditas pertanian, perkembangan ekonomi Ambarawa tidak dibarengi dengan perkembangan sektor pertanian di Ambarawa. Hal ini dapat dilihat dari atas PDRB harga konstan Kecamatan Ambarawa tahun 2009, sektror yang saat ini memberikan kontribusi tertinggi adalah sektor perdagangan, rumah makan, dan jasa akomodasi (44\%), selanjutnya sektor jasa-jasa (23\%), dan kemudian sektro pertanian (13\%). Hal ini mengindikasikan bahwa sebagai pemasok komoditas pertanian, tidak berdampak pada pertumbuhan di sektor pertanian di Ambarawa, bahkan dari tahun ke tahun pendapatan sektor pertanian Ambarawa mengalami penurunan. Artinya sektor pertanian bukan menjadi sektor penggerak utama bagi masyarakat Ambarawa pada umumnya, hal ini juga menurunkan pendapatan petani dan pedagang komoditas pertanian di Ambarawa. Untuk memperkuat pendapat tersebut, maka dilakukan analisis rantai pasar di Pasar Projo sebagai pemasok komoditas pertanian utama di Ambarawa. Analisis rantai pasar tersebut akan menjawab siapa saja pelaku, nilai tambah, bentuk, dan lokasi rantai pasar komoditas pertanian tersebut. Dari analisis rantai pasar tersebut akan dapat diketahui dampak Pasar Projo terhadap kegiatan perdagangan komoditas pertanian. Apakah hubungan rantai pasar dengan kegiatan perdagangan berdampak positif dan negatif bagi pedagang di Pasar Projo.

\section{Tujuan dan Sasaran Penelitian}

Penelitian ini bertujuan untuk mengetahui aktivitas rantai pasar komoditas pertanian dan dampaknya terhadap kegiatan perdagangan komoditas pertanian di Pasar Projo, Kecamatan Ambarawa. Adapun sasaran penelitian ini adalah:

1. Mengidentifikasi pelaku rantai pasar komoditas pertanian.

2. Mengidentifikasi lokasi rantai pasar komoditas pertanian.

3. Mengidentifikasi bentuk rantai pasar komoditas pertanian.

4. Mengidentifikasi nilai tambah rantai pasar komoditas pertanian.

5. Menganalisis dampak aktivitas rantai pasar terhadap kegiatan perdagangan komoditas pertanian.

\section{Tinjauan Teoritis}

\section{Peran Kota dalam Sistem Wilayah}

Peran kota-kota dalam sistem wilayah lebih didasarkan pada pusat pelayananya, sedangkan desa-desa sebagai bagian dari wilayah sebagai pemasok barang dan jasa bagi kota-kota. Hal inilah yang dinamakan keterkaitan antara kota dan desa. Kota menurut Ahmadin adalah sebagai suatu lokasi yang angka kepadatan penduduknya lebih tinggi dari wilayah sekitarnya, kegiatan masyarakatnya bukan di bidang pertanian, lokasi tersebut sebagai pusat kebudayaan, administrasi, atau punpusat kegiatan ekonomi bagi wilayah sekitarnya (Ahmadin, 1993: 27). Sedangkan fungsi kota adalah sebagai penyelenggara dan penyediaan jasa-jasa bagi wilayah sekitarnya, sehingga kota disebut pusat pelayanan. Jadi kota pertama kali muncul sebagai pusat pelayanan, bukan pusat permukiman. Kota menjadi pusat pelayanan bergantung pada pedesaan sekitarnya memanfaatkan jasa-jasa kota tersebut (Daldjoeni, $1987: 27-28$ ).

Peran kota dalam wilayah dapat diartikan sebagai pusat kegiatan pelayanan biasanya dapat memberikan kontribusi terbesar dan meningkatkan pada GNP (Soegijoko, 2005: 25). Aktivitas kegiatan pelayanan ini dapat dikelompokkan dalam 3 kategori utama, yaitu : 
- Pelayanan konsumen yang meliputi kegiatan distribusi seperti perdagangan grosir, eceran, hiburan, dan rekreasi (hotel, restoran), serta pelayanan pribadi (salon, spa, dan sebagainya)

- Pelayanan produksi yang menyediakan input atau terkait dengan aktivitas ekonomi lain sebagai bagian dari suatu proses produksi. Contohnya transportasi; komunikasi; utilitas (listrik,air gas); jasa keuangan; asuransi; real estate; serta jasa pelayanan perusahaan (advertensi, penyediaan tenaga kerja, jasa-jasa, konsultan, dan sebagainya).

- Pelayanan publik dan pemerintahan yang sebagian besar disediakan oleh danadana publik. Contohnya administrasi publik, yaitu upaya-upaya pemerintah dalam pengelolaan pembangunan; penanggulangan masalah-masalah sosial seperti kemiskinan, pengangguran; pelayanan sosial seperti kesehatan dan pendidikan

\section{Sistem Kota}

Dalam mendefinisikan sistem dapat dimulai dengan mendefinisikan sistem dan kota. Sistem menurut Lucas (dalam Djakapermana, 2010) menyatakan bahwa secara teoritis komponen- komponen dalam suatu sistem saling berhubungan dan memiliki ketergantungan antar komponen. Sebagai sustu sistem, subsistem penyusunya akan saling berhubungan melalui berbagai bentuk interaksi dan bekerjasama untuk mencapai suatu tujuan yang berguna. Sedangkan Kota menurut Rondinelli (1983:153) adalah tempattempat yang menjadi pusat kegiatan administratif telah mendapatkan keuntungan dari investasi infrastruktur dan kegiatan jasa yang tertarik untuk bertempat di lokasi tersebut karena status politiknya. Jadi sistem kota adalah tempat-tempat administratif (kota) sebagai komponen utama pembentuk sistem yang saling berhubungan dengan komponen lain (kota kecil atau desa) dalam bentuk interaksi untuk mencapai tujuan bersama.

Pendapat berbeda dikemukakan oleh Purboyo (2002), menurut purboyo sistem perkotaan adalah hubungan saling terkait yang terjadi dalam kumpulan kota-kota dengan interaksi yang saling menguntungkan bagi kota- kota tersebut. Konsep sistem bergantung pada adanya interaksi sebagai faktor pengikat, sehingga ketiadaan interaksi dapat membatalkan konsep itu meski kumpulan kota- kota itu dapat dilihat secara nyata. Interkasi saling menguntungkan yang mampu memeratakan kesejahteraan dan menjamin penyebaran pertumbuhan ke wilayah belakang pada dasarnya menjadi penentu eksistensi sistem perkotaan. Oleh karena itu, hirarki kota yang mengatur pembagian peran dalam sistem akan mempengaruhi kinerja pelayanan kota.

Dalam suatu sistem perkotaan, kota merupakan unsur atau elemen utama dan merupakan simpul-simpul atau nodes dalam sistem ini. Sedangkan hubungan atau interaksi antar simpul ini merupakan faktor pembentuk sistem ini, dan terwujudkan sebagai aliranaliran dalam suatu jejaring. Ada 4 peran penting yang diemban oleh interaksi atau keterkaitan antar simpul ini. Peran pertama adalah mewujudkan integrasi spasial. Manusia dan kegiatannnya terpisah-pisah dalam ruang, sehingga interaksi ini penting untuk menerkaitkannya. Peran kedua dari interaksi atau keterkaitan ini adalah memungkinkan adanya diferensiasi dan spesialisasi dalam sistem perkotaan. Peran ketiga dan yang paling penting adaalah sebagai wahana untuk pengorganisasian kegiatan dalam ruang dan peran keempat adalah dalam memfasilitasi serta menyalurkan perubahan- perubahan dari satu simpul ke simpul lalinnya. (Soegijoko, $2005: 22$ ) 


\section{Mobilitas Penduduk (Masyarakat)}

Dalam konteks sosial, mobilitas penduduk merupakan bentuk kemajuan sosial masyarakat. Produktivitas masyarakat yang semakin tinggi membuat masyarakat melakukan mobilitas dengan berinteraksi dengan penduduk kota lain. Mobilitas penduduk adalah perpindahan dari tempat satu ke tempat yang lain. Hal ini dilatarbelakangi oleh desakan pemenuhan kebutuhan hidupnya setiap harinya (Parnwell, 1993:76).

Pergerakan masyarakat disebabkan oleh perbedaan kondisi dari dua ruang yang berbeda. Ada beberapa faktor yang menyebabkan terjadinya pergerakan masyarakat pada suatu wilayah, beberapa faktor ini dikelompokkan ke dalam dua kelompok faktor. Adapun kedua kelompok tersebut antara lain faktor pendorong merupakan faktor-faktor yang mendorong masyarakat untuk melakukan pergerakan. Faktor-faktor ini merupakan pencerminan kondisi yang ada di daerah asal. Adapun beberapa faktor tersebut antara lain; pertumbuhan populasi yang tinggi, produktivitas pertanian yang memberikan pendapatan rendah, dan lemahnya sektor non-pertanian dalam memberikan kontribusi pendapatan masyarakat. Sedangkan faktor yang kedua adalah faktor penarik, merupakan faktor-faktor penarik masyarakat untuk melakukan pergerakan dari daerah asal. Faktor-faktor ini lebih menggambarkan pada kondisi daerah tujuan (Parnwell, 1993: 78).

\section{Pasar}

Pasar mempunyai pengertian yang beragam, Pasar menurut Stanton (1984:92) adalah tempat dimana pembeli bertemu dengan penjual, barang-barang atau jasa-jasa ditawarkan untuk dijual dan kemudian terjadi pemindahan hak milik dan juga didefinisikan sebagai permintaan yang diajukan oleh sekelompok pembeli yang potensial untuk sebuah produk atau jasa. Sedangkan menurut Belshaw (1981), pasar merupakan suatu sistem yang menghasillkan peraturan harga-harga dengan sendirinya. Pengaturan ini terjadi melalui interaksi antara pembeli dan penjual, yang bertindak tanpa pandang bulu, artinya tanpa memandang kekerabatan, status, perasaan, atau faktor lain diluar kedudukannya sebagai pembeli dan penjual. Pasar menurut Kementerian Koperasi dan Usaha Kecil dan Menengah adalah lembaga ekonomi dimana para pembeli dan penjual baik secara langsung maupun tidak langsung dapat melakukan transaksi perdagangan barang dan jasa. Berdasarkan pengertian di atas, dapat disimpulkan bahwa pasar adalah tempat transaksi antara penjual dan pembeli secara langsung maupun tidak langsung dimana terdapat pengaturan harga tanpa pandang bulu.

Secara umum pasar dapat diklasifikasikan kedalam tiga kategori, yaitu:

1. Pasar tradisional merupakan pasar dengan area jual beli yang dikembangkan dengan area jual beli yang dikembangkan dan dikelola secara resmi oleh PEMDA dimana aktivitas tersebut hanya didukung oleh jumlah sarana serta tingkat kenyamanan yang relatif secukupnya.

2. Pasar modern yaitu pasar dengan jual beli berbagai jenis barang yang dikelola secara terpadu dan pada umumnya menerapkan pasar swalayan. Karakteridtik yang terpenting dari pola pasar ini adalah adanya pengelolaan modern seperti manajemen, tekonologi, serta promosi yang agresif, disamping tersedianya sarana belanja umum yang mewah, teratur, bersih, dan nyaman. Pasar swalayan (supermarket), department store, pusat perbelanjaan seperti mall dan plaza termasuk dalam kategori pasar ini.

3. Pasar informal, merupakan pasar dengan area jual beli yang menepati lokasi secara tidak legal, sehingga aktivitas perdagangan yang terjadi berlangsung dalam suasana darurat dan seadanya. Pasar ini tidak memiliki sarana penunjang, pengaturan, maupun kenyamanan berbelanja. Pasar ini biasanya terdapat disekitar pasar formal, titik keramaian dijalan raya atau wilayah permukiman. 
Berdasarkan konsumen, perbaikan fisik bangunan pasar, dan strategis letaknya, pasar dapat dikategorikan menjadi 4 yaitu:

1. Pasar lingkungan adalah pasar yang jangkauan pelayanan konsumennya hanya meliputi daerah sekitar pasar, komoditi yang dipasarkan terbatas pada kebutuhan rumah tangga.

2. Pasar wilayah merupakan pasar yang jangkauan pelayananya meliputi beberapa lingkungan permukiman dalam lingkup kecamatan. Di pasar ini terdapat komoditi modern yang relatif mahal. Karakteristik bangunan pasar ini memiliki ukuran yang relatif lebih besar dibandingkan dengan pasar lingkungan.

3. Pasar kota, yaitu pasar yang jangkauan pelayanannya meliputi wilayah kota dan daerah luar sekitar kota tersebut. Barang-barang yang diperdagangkan relatif lebih banyak dibandingkan dengan pasar wilayah dan lingkungan.

4. Pasar regional, merupakan pasar dengan jangkauan pelayanan yang meliputi kota, wilayah lokal, wilayah sekitar dan wilayah regional. Karakteristik fisik bangunan dan fasilitas penunjang pasar regional relatif lebih bagus dibandingkan dengan pasar dibawahnya.

Menurut Murtolo (1995), peranan pasar dibedakan menjadi dua yaitu sebagai pusat ekonomi dan kebudayaan. Kedua peranan tersebut penjabarannya adalah sebagai berikut:

1. Pasar sebagai pusat ekonomi. Pasar sebagai pusat ekonomi, maksudnya adalah bahwa pasar adalah tempat yang digunakan untuk kegitan ekonomi (menghasilkan uang) dan dengan keberadaan pasar tersebut diharapkan mampu membangkitkan ekonomi masyarakat sekitar. Pasar sebagi pusat ekonomi dibagi menjadi tiga hal, yaitu :

a. Sistem Produksi

Produksi merupakan kegiatan menghasilkan suatu barang, dalam hal ini pasar memiliki peranan sebagai tempat penjualan komoditas dari berbagai wilayah. Sehinggan produksi ini dilihat dari sisi penjual.

b. Sistem Konsumsi

Konsumsi adalah proses kebalikan dari produksi, artinya adalah kegiatan memakai atau menggunakan barang. Konsumsi dilihat dari sisi pembeli.

c. Sistem Distribusi

Distribusi merupakan proses penyampaian dari produsen kepada konsumen, artinya pasar sebagai tempat untuk bertransaksi atau tempat jual beli komoditas.

2. Pasar sebagi pusat kebudayaan. Pasar sebagai pusat kebudayaan ini meliputi :

a. Pasar sebagai sarana pembauran

b. Pasar sebagai pusat informasi

\section{Rantai Pasar}

Rantai pasar merupakan sebuah rantai yang digunakanuntuk menggambarkan sejumlah jaringan yang menghubungkan semua pelaku terkait dan transaksi yang terjadi dalam pergerakan barang pertanian dari pertanian ke konsumen (Lundy.et al, 2004:15). Rantai pasar juga dapat diartikan hubungan dari produsen ke konsumen yang melibatkan kegiatan saling terkait (Ferris.et al, 2006). Tujuan dari rantai pasar adalah untuk mendapatkan lebih rinci pemahaman tentang aktor, kegiatan, biaya, dan peluang terkait dengan aliran produk tertentu dan terkait layanan, dimulai dengan petani dan berakhir dengan pembeli yang ditargetkan atau konsumen Efisiensi rantai pasar umumnya merupakan faktor tentang bagaimana juga arus informasi antara pelaku. Analisis rantai pasar digunakan untuk mengidentifikasi dan menjelaskan semua titik dalam rantai tersebut. Informasi diperoleh 
melalui analisis rantai pasar juga membantu dalam mengidentifikasi rantai pasar terbaik untuk klien tertentu dan lokasi kunci pelaku rantai pasar yang akan membeli produk (Lundy.et al, 2004:17).

Ruang dalam struktur ruang komoditas ini merupakan wilayah fungsional yang lokasinya mungkin berada di dalam dan di luar wilayah administrasi daerah sentra produksi komoditas (Kaplinsky dan Morris, 2000:4). Rangkaian proses dalam rantai komoditas menimbulkan keterkaitan antar aktivitas dan pelaku yang memberikan nilai tambah. Ruang dalam hal ini sangat berkaitan dengan lokasi dalam rantai pasar yang digambarkan dengan perpindahan komoditas pertanian dari lokasi satu ke lokasi lainnya. Lokasi dalam rantai ini berkaitan dengan komoditas yang dihasilkan oleh petani tidak dapat langsung dinikmati oleh konsumen dan dibutuhkan distribusi untuk memindahkan komoditas tersebut ke lokasi pemasaran. Itulah yang menjadi penggambaran lokasi rantai pasar komoditas. Komponen rantai pasar dapat dilihat di gambar 4.1 di bawah ini.

\begin{tabular}{|c|c|c|}
\hline Produksi & $\begin{array}{c}\text { Manajemen Pengolahan } \\
\text { Pasca Panen }\end{array}$ & Pemasaran \\
\hline $\begin{array}{l}\text { Fungsi: } \\
\text { - } \text { Perencanaan dan } \\
\text { organisasi faktor } \\
\text { produksi } \\
\text { - Akses ke sumber daya } \\
\text { - Produksi } \\
\text { - Panen } \\
\text { - Penjualan Produk }\end{array}$ & $\begin{array}{l}\text { Fungsi: } \\
\text { - Koleksi } \\
\text { - Seleksi } \\
\text { - Pengemasan } \\
\text { - Diferensiasi Produk } \\
\text { - Nilai Tambah } \\
\text { - Transportasi } \\
\text { - Penjualan Produk }\end{array}$ & $\begin{array}{l}\text { Fungsi: } \\
\text { - Kontak pembeli } \\
\text { - Negosiasi pasar } \\
\text { - Negosiasi produk } \\
\text { - Negosiasi harga dan } \\
\text { kondisi } \\
\text { - } \text { Penyampaian produk ke } \\
\text { klien }\end{array}$ \\
\hline
\end{tabular}

Sumber: Lundy.et al, 2004

\section{Gambar 1. Komponen Rantai Pasar}

Pada gambar diatas menggambarkan bahwa fungsi produksi pada rantai komoditas pertanian dijalankan oleh petani sebagai produsen yang menjalankan peran perencanaan dan organisasi produk. Untuk fungsi manajemen pasca panen dijalankan oleh pengumpul desa dan pedagang pengumpul yang menyortir dan membungkus sayuran agar lebih tahan lama dan menambah nilai tambah kemudian menjual produk ke pasaran baik pasar besar maupun pasar kecil. Sedangkan untuk aspek pemasaran dijalankan oleh pedagang baik itu pengumpul, pedagang pasar, dan pedagang pengecer yang mengontak pembeli dan menetapkan harga ke pembeli.

Pada tahapan proses rantai pasar dimulai dari produsen, perdagangan, dan sampai ke konsumen. Proses rantai pasar ini menunjukkan rantai yang ada, yaitu pelaku-pelaku kegiatan rantai pasar akan dapat diketahui. Dalam tahapan rantai pasar, dibutuhkan dukungan- dukungan bagi pelaku rantai seperti pasokan produksi, jasa keuangan, informasi pasar, transportasi, dan penelitian. Dukungan- dukungan pelayanan ini biasanya terdapat di kota besar tetapi sangat sedikit terdapat di pedesaan.

Ada tiga aspek kunci yang digunakan untuk memahami bagaimana sebuah rantai pasar beroperasi, pertama adalah tingkat pengembangan bisnis organisasi yang berpartisipasi, kedua adalah penyediaan layanan pengembangan bisnis dan ketiga adalah 
konteks rantai pasar yang beroperasi. Dalam hal ini pasar tradisional, keterbatasan pendekatan rantai pasar tradisional adalah bahwa ia cenderung untuk mempersempit pelaku dalam isolasi dan tidak memperhitungkan ketajaman bisnis para pemain. Artinya dalam pasar tradisional mengabaikan organisasi baik negeri maupun swasta yang menyediakan layanan pengembangan usaha ke rantai pasar. Bisnis tersebut adalah tentang organisasi bisnis sepanjang rantai pasar dan para aktor yang membentuk proses mendukung bisnis, akan membentuk desain strategi yang menjadi kekuatan bagi pelaku rantai. Seperti telah disebutkan sebelumnya, rantai pasar beroperasi paling kompetitif ketika mereka didukung oleh organisasi bisnis berdedikasi, baik formal maupun informal, yang berpartisipasi dalam memungkinkan menghasilkan aliran yang lancar dari petani ke konsumen akhir. Penggunaan pendekatan rantai pasar diatas juga memiliki beberapa keuntungan, yaitu:

1. Rantai pasar memungkinkan visi yang lebih lengkap karena peran yang dimainkan aktor yangberbeda dalam kerangka bisnis;

2. Membagi rantai menjadi fungsi dan aktor- aktor memberikan dasar tingkat pertama untuk melihat siapa yang melakukan fungsi, kepentingan dan memungkinkan kelompok produsen dan penyedia pelayanan memahami proses manajemen;

3. Akses ke informasi yang lebih lengkap memfasilitasi untuk mengetahui titik kritis penghambat pengembangan rantai pasar, dimana perbaikan dan intervensi a lternatif dapat diterapkan sehingga investasi dalam rantai pasar tertentu dapat menjadi efektif;

4. Visi rantai pasar dengan beberapa pelaku memfasi litasi pembentukan aliansi dan sinergi antar pelaku yang berbeda melalui identifikasi kepentingan bersama dan pengurangan transaksi biaya yang lebih efisien untuk penggunaan sumber daya yang tersedia (Lundy.et al, 2004:25).

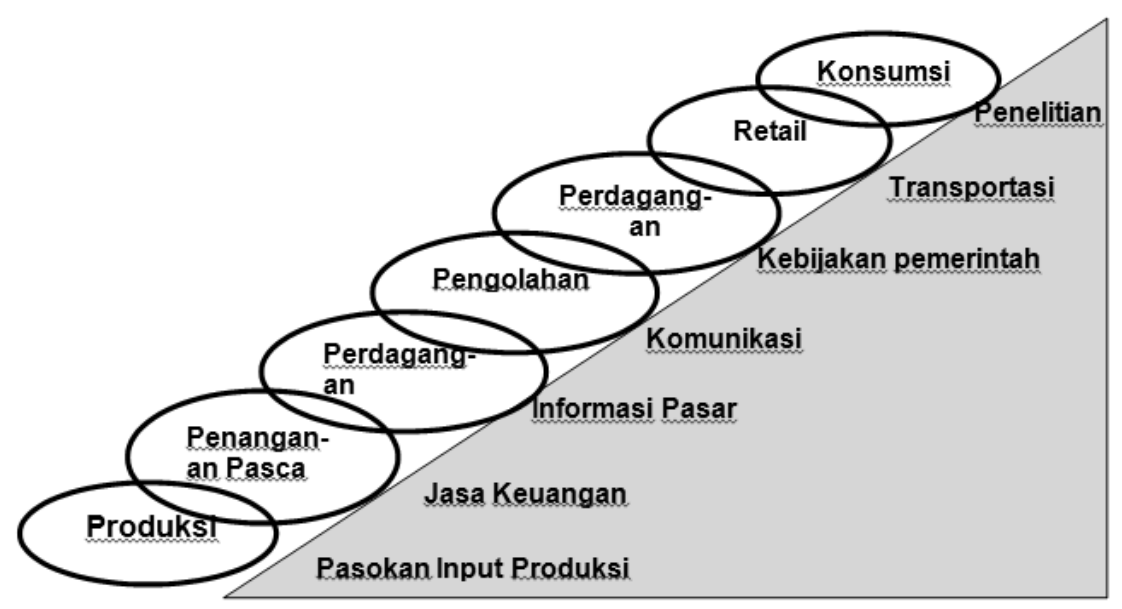

Sumber: Lundy.et al, 2004

Gambar 2. Jaringan Antar Rantai Pasar dan Dukungan Pelayanan Bisnis

\section{Metode Penelitian}

Penelitian tentang Rantai Pasar Komoditas Pertanian dan Dampaknya Terhadap Kegiatan Perdagangan Komoditas Pertanian merupakan sebuah penelitian kualitatif yang merupakan suatu pendekatan atau mengeksplorasian suatu gejala sentral dengan mewawancarai narasumber dengan pertanyaan umum dan luas. Informasi tersebut biasanya berupa kata 


\section{Rantai Pasar Komoditas Pertanian dan Dampaknya Terhadap Kegiatan Perdagangan Komoditas Pertanian}

dan teks yang kemudian di analisis dengan hasil berupa penggambaran atau deksripsi atau dapat pula dalam bentuk tema-tema (Cresweell dalam Raco, 2010: 7).

Penelitian yang akan dilakukan pada penelitian ini menggunakan metode penelitian studi kasus. Penelitian studi kasus menurut Yunus (2010: 264) adalah penelitian dimana anggota yang diteliti tidak diharapkan dapat memberikan gambaran mengenai karakteristik seluruh anggota populasi, hasil penelitiannya secara khusus berlaku pada obyek yang bersangkutan. Obyek penelitian pada penelitian studi kasus ini adalah menceritakan karakteristik obyek itu sendiri secara mendalam (eksploratif) sehingga data tentang obyek tersebut dikumpulkan secara detail untuk memperoleh gambaran utuh dari objek dalam artian bahwa data yang dikumpulkan dalam studi dipelajari sebagai keseluruhan, utuh yang terintegrasi.

Artinya dalam penelitian rantai pasar komoditas pertanian ini, dibutuhkan pemahaman mendalam dari peran tiap pelaku dalam aliran rantai pasar komoditas pertanian. Dari pemahaman tersebut akan didapatkan penggambaran rantai pasar komoditas pertanian yaitu pelaku, lokasi, bentuk, dan nilai tambah rantai pasar. Berikut akan dijelaskan obyek penelitian dan skenario wawancara dimana pedagang pasar sebagai kunci dalam penelitian ini.

Penelitian ini menggunakan teknik sampling snowballing dengan cara memberikan pertanyaan kepada informan kunci dan akan terus bergulir kepada orang-orang yang memiliki keterkaitan aliran rantai pasar ini. Seperti yang disbutkan dalam obyek penelitian, maka informan kunci dalam penelitian ini adalah 10 pedagang pasar yang akan memberikan informasi terkait yang akan dijadikan anggota sampel sesuai dengan maksud dan tujuan studi. Penambahan sampel akan terus dilakukan hingga semua pelaku terkait telah diwawancarai. Penambahan sampel juga dihentikan jika data yang dihasilkan sudah jenuh, yaitu bila tidak diperoleh data baru lagi. Sesuai dengan uraian di atas, obyek penelitian dan skenario pada penelitian yang diwawancarai ini dibagi menjadi 2, yaitu pelaku komoditas sayuran dan pelaku komoditas buah. Teknik pengumpulan data penelitian ini adalah dengan wawancara dan observasi. Sedangkan teknis analisis adalah statistik deskriptif juga digunakan untuk menganalisis rantai pasar komoditas pertanian.

\section{Analisis Rantai Pasar Komoditas Pertanian dan Dampaknya Terhadap Kegiatan Perdagangan Komoditas Pertanian}

\section{Analisis Rantai Pelaku Komoditas Pertanian}

Analisis rantai pelaku komoditas pertanian di Pasar Projo dibagi menjadi 2, yaitu rantai pelaku sayuran dan buah. Rantai pelaku sayuran terdiri dari petani, pedagang desa, pengumpul desa, pedagang pengumpul, pedagang pengecer, pelaku industry kecil sayuran dan konsumen. Keberadaan petani, pedagang/pengumpul desa, dan pedagang pengumpul pada rantai pasar ini, sangat berperan pada keberadaan komoditas sayuran di Pasar Projo. Petani sebagai produsen sangat berperan terhadap penghasil sayuran, sedangkan pedagang/pengumpul desa dan pedagang pengumpul berperan terhadap pendistribusian sayuran di Pasar Projo. Pelaku pedagang pasar dan pedagang pengecer berperan terhadap penjualan sayuran di Pasar Projo kepada konsumen. Sedangkan untuk pelaku industri kecil merupupakan pelaku yang memakai sayuran sebagai bahan bakunya dan pelaku ini membeli sayuran di Pasar Projo. Kapasitas berjualan antar pelaku berbeda-beda, kapasitas terbesar adalah pedagang pengumpul dengan maksimal 2 Ton dari jumlah semua sayuran, sedangkan kapasitas berjualan terkecil yaitu pedagang pengecer dengan maksimal $30 \mathrm{Kg}$ dari semua sayuran. Dibawah ini merupakan penggambaran rantai pelaku sayuran. 


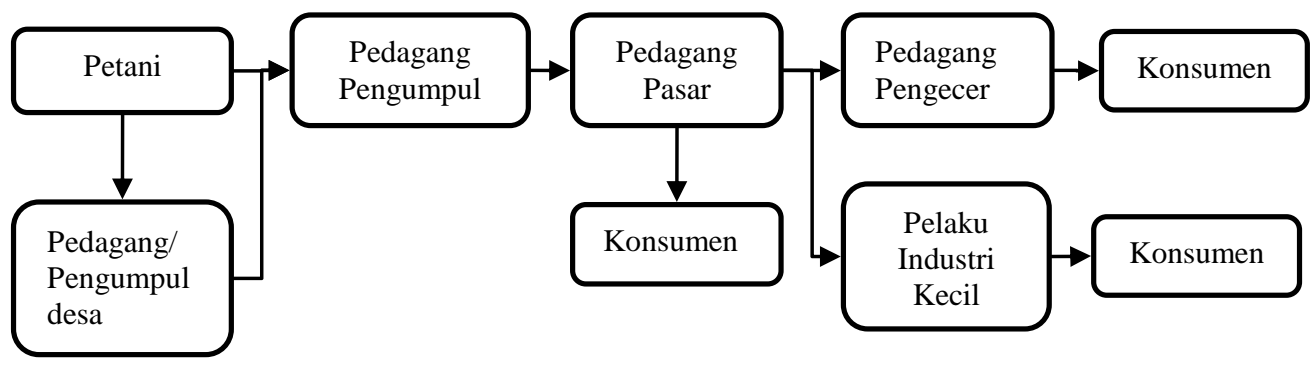

\section{Gambar 3. Rantai Pelaku Sayuran}

Rantai pelaku buah merupakan penggabungan antara pelaku buah lokal dan buah impor. Rantai pelaku buah lokal terdiri dari petani, pengumpul desa, pengumpul Pasar Johar, pengumpul Pasar Projo, pedagang pasar, dan konsumen. Sedangkan untuk pelaku buah impor terdiri dari petani, supplier, eksportir importir, pedagang retail, pengumpul Pasar Johar, pengumpul Pasar Projo, pedagang pasar, dan konsumen. Dari data di atas dapat digambarkan bahwa pelaku buah impor lebih banyak dibandingkan rantai pelaku buah lokal. Hal ini dikarenakan pelaku buah impor merupakan penggabungan antara pelaku local dan luar negeri.

Rantai pelaku komoditas buah lebih panjang dibandingkan pelaku komoditas sayuran. Pelaku untuk buah impor lebih banyak dibandingkan buah lokal. Keberadaan pengumpul Pasar Projo merupakan pelaku kunci sebagai distributor buah impor dan buah lokal di Pasar Projo. Dengan rantai yang lebih panjang membuat harga buah lebih mahal dibandingkan harga sayuran. Karena pelaku rantai buah lebih panjang, maka harga buah yang dijual cenderung tinggi jika mencapai pedagang pasar baik buah lokal dan impor, terutama buah jeruk, apel, dan pir. Mahalnya harga buah dipengaruhi oleh faktor musim yang membuat keberadaan buah menjadi lebih singkat. Sedangkan untuk buah papaya dan semangka tidak tergantung musim dan cukup mudah dibudidayakan sehingga harganya pun cukup murah hingga mencapai pedagang pasar. Dibawah ini merupakan penggambaran rantai pelaku buah local dan impor.

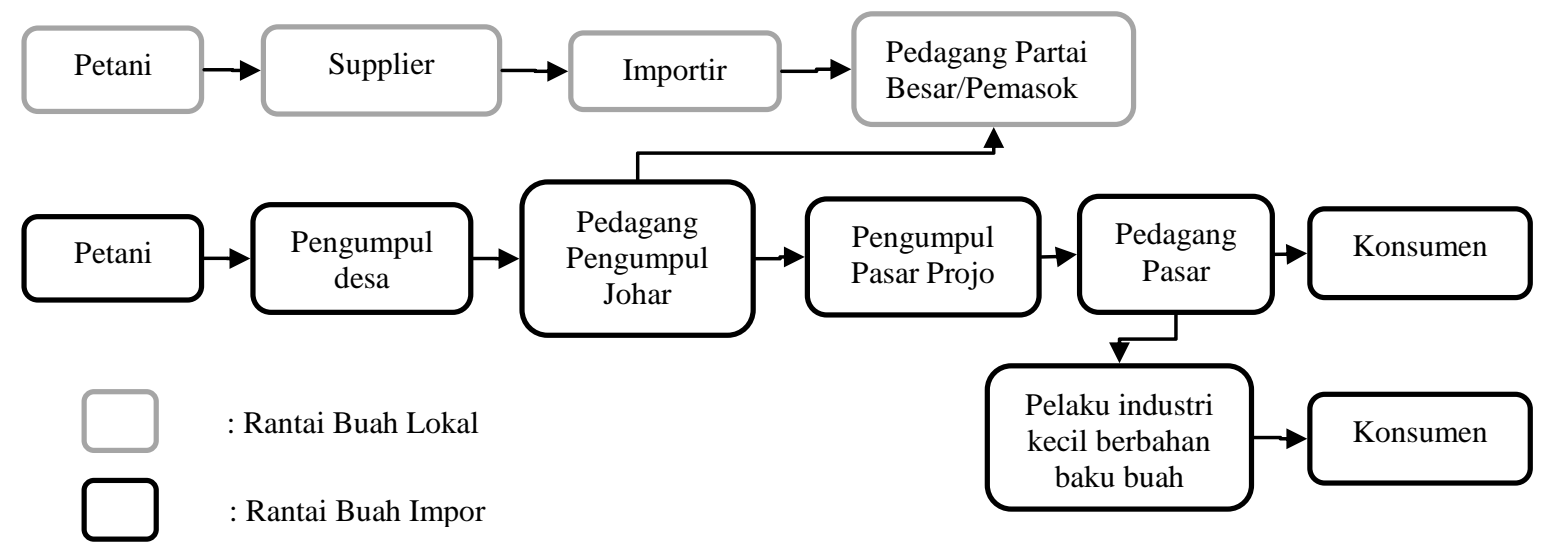

Gambar 4. Rantai Pelaku Buah 


\section{Rantai Pasar Komoditas Pertanian dan Dampaknya Terhadap Kegiatan Perdagangan Komoditas Pertanian}

\section{Analisis Lokasi Rantai Pasar Komoditas Pertanian}

Rantai pasar komoditas juga menimbulkan struktur keruangan akibat lokasi-lokasi aktivitas dan pelaku yang berbeda (Kaplinsky dan Morris, 2000:4). Ruang dalam hal ini sangat berkaitan dengan lokasi dalam rantai pasar yang digambarkan dengan perpindahan komoditas pertanian dari lokasi satu ke lokasi lainnya. Inilah latar belakang analisis lokasi rantai pasar komoditas pertanian di Pasar Projo. Artinya sentra komoditas pertanian di Pasar Projo tidak harus berada di Ambarawa sendiri, sentra tersebut dapat berupa di luar Ambarawa, kabupaten, provinsi, ataupun Negara. Dalam analisis lokasi ini, akan di bagi menjadi 2 bagian, yaitu analisis asal komoditas pertanian di Pasar Projo dan analisis tujuan komoditas pertanian di Pasar Projo. Analisis asal komoditas pertanian di Pasar Projo ini dimaksudkan untuk menggambarkan asal muasal sayuran dan buah di Pasar Projo. Analisis ini sangat berkaitan dengan ruang yang berkaitan dengan lokasi sentra dan pemasaran komoditas yang berbeda.

Ruang dalam struktur ruang komoditas ini merupakan wilayah fungsional yang lokasinya mungkin berada di dalam dan di luar wilayah administrasi daerah sentra produksi komoditas (Kaplinsky dan Morris, 2000:4). Pasar Projo merupakan pasar yang digunakan masyarakat untuk mendistribusikan sayuran dan buah- buahan. Berikut merupakan asal komoditas sayuran di Pasar Projo:

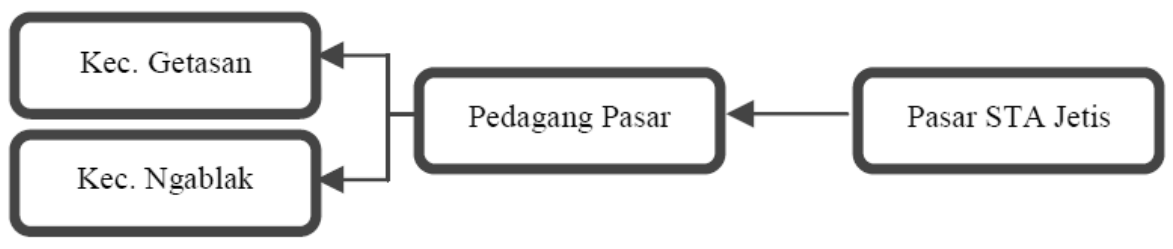

\section{Gambar 5. Asal Komoditas Sayuran di Pasar Projo}

Komoditas sayuran di Pasar Projo berasal dari pedagang pengumpul sayuran yang membawa dari petani daerah masing-masing. Sehingga asal sayuran di Pasar Projo sebagian besar adalah berasal dari Kecamatan Getasan dan Kecamatan Ngablak. Sedangkan untuk aliran antar pasar terjadi dengan Pasar sayuran STA Jetis, dimana pedagang pasar Projo membeli sayuran di Pasar STA Jetis kemudian dijual kembali di Pasar Projo. Dari hasil pengamatan, diketahui bahwa sebagian besar pedagang pasar yang membeli sayuran di Pasar STA Jetis dikarenakan kedekatan lokasi dan tingkat kepercayaan terhadap pasar tersebut. Dapat disimpulkan bahwa lokasi sentra komoditas sayuran dan pemasarannya berbeda.

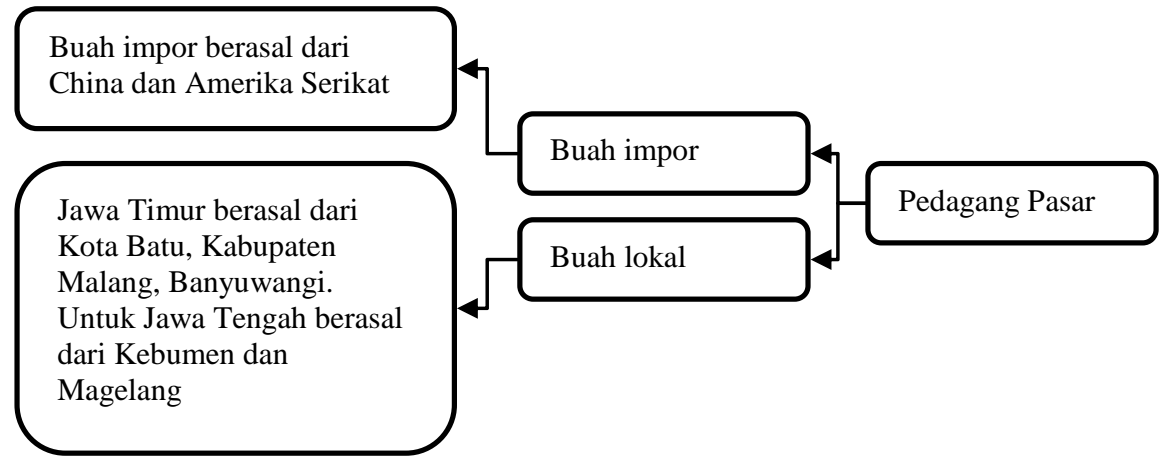

Gambar 6. Asal Komoditas Buah di Pasar Projo 
Sentra komoditas sayuran berada di Kec. Getasan dan Kec. Ngablak, sementara pemasaran berada di Pasar Projo, Kec. Ambarawa. Sedangkan untuk asal buah-buahan yang dijual di Pasar Projo, sebagian berasal didominasi oleh Provinsi Jawa Timur yang merupakan penghasil buah seperti apel malang, jeruk keprok, papaya, dan semangka. Selain itu buah di Pasar Projo terdapat oleh buah impor seperti apel fuji, apel merah, dan pir, ketiga buah tersebut berasal dari China dan Amerika Serikat. Untuk mendapatkan komoditas buah- buahan tersebut, pedagang pasar mendapatkan dari pedagang pengumpul yang membeli di Pasar Pasar Johar.

Untuk komoditas buah-buahan, sebagian besar buah lokal yang dijual oleh pedagang pasar Projo adalah berasal dari sentra penghasil buah di Jawa Timur. Contohnya adalah semangka, papaya, jeruk keprok, dan apel malang yang berasal dari Kediri, Banyuwangi, Kabupaten Malang, dan Kota Batu. Sedangkan untuk Jawa Tengah, daerah tersebut adalah Kebumen dan Magelang yang menghasilkan semangka dan papaya. Sementara untuk buah impor seperti buah apel fuji, apel merah, dan pir berasal dari China dan Amerika Serikat.

Untuk tujuan komoditas pertanian, Pasar Projo yang memiliki pasar khusus sayuran yaitu pasar pagi yang wilayah memiliki pemasaran yang tidak hanya tingkat lokal Ambarawa sendiri, tetapi juga wilayah kabupaten sampai Kota Semarang. Dengan kapasitas pedagang pasar buah dan sayuran di Pasar Projo hanya sampai 1 sampai 3 kwintal sayuran menyebabkan pedagang pasar tidak mampu untuk melayani permintaan sayuran yang cukup besar. Karena dengan kapasitas yang besar merupakan kunci luasnya wilayah pemasaran sayuran di Kabupaten Semarang seperti di Pasar STA Jetis. maka luasnya pemasaran di Pasar Projo sangat bergantung pada pedagang pengecer yang memiliki mobilitas tinggi. Hal ini dikarenakan pedagang pengecer mempunyai transportasi mobil dan motor yang akan menjual menjual sesuai wilayah penjualan mereka. Keberadaan pedagang pengecer mempunyai peran yang penting terhadap luasnya penjualan komoditas, hal ini terlihat dari komoditas buah- buahan yang tidak memiliki pelaku pedagang pengecer dalam rantai ini, maka penjualan buah-buahan di Pasar Projo hanya mencakup daerah yang terdekat dengan Ambarawa yaitu Kecamatan Rawa Pening, Jambu dan Bawen

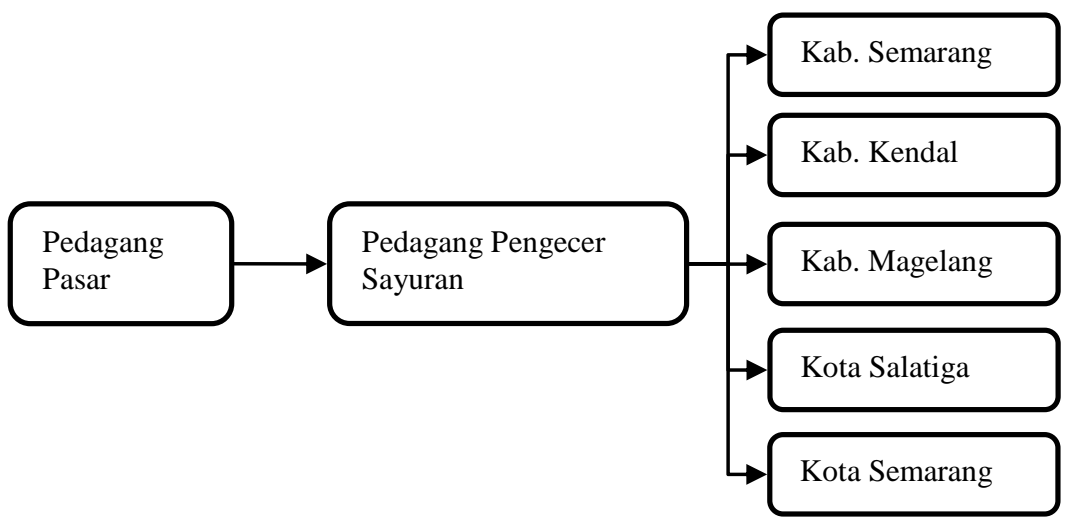

Gambar 7. Tujuan Komoditas Sayuran di Pasar Projo

Pasar Projo sebagai pasar komoditas sayuran dan buah merupakan pasar regional yang wilayah pemasarannya wilayah lokal, wilayah sekitar dan wilayah regional. Walaupun dapat disebut pasar regional, tetapi pedagang pasar masih belum dapat melayani pelanggan dengan jumlah yang cukup besar karena kapasitas yang dijual pedagang pasar masih kecil untuk ukuran pasar regional. Pedagang pasar komoditas buah dan sayuran di 
Pasar Projo hanya dapat melayani konsumen lokal dan konsumen yang berada di sekitar Ambarawa.

\section{Analisis Bentuk Rantai Pasar Komoditas Pertanian}

Untuk rantai bentuk komoditas sayuran dan buah di Pasar Projo dapat dilihat pada gambar dibawah ini:

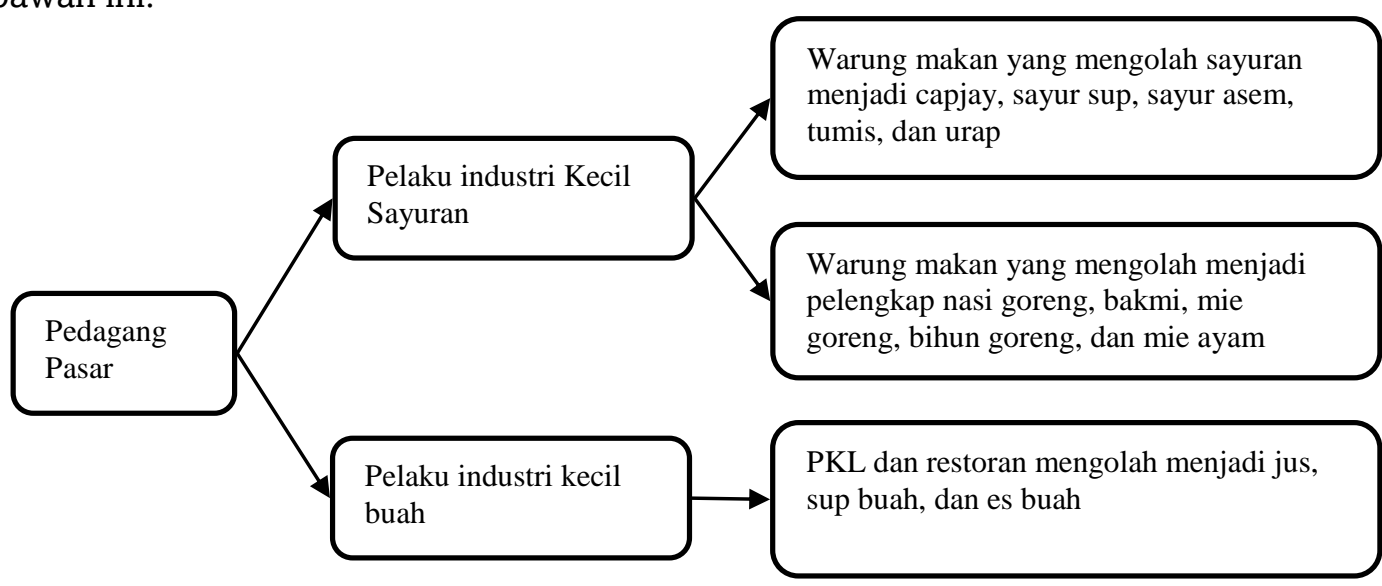

Gambar 8. Bentuk Rantai Komoditas Pertanian

Sebagian pelaku industri ini merupakan pelaku yang memakai bahan dasar sayuran untuk diolah menjadi bentuk lainnya, seperti warung makan, restoran, dan pkl yang mengolah menjadi makanan, sayur, jus, sup buah, dll. Sebagian besar pelaku ini merupakan pelaku rumah makan dan restoran. Tidak adanya pelaku industri besar yang membeli di Pasar Projo dikarenakan kapasitas pedagang pasar maksimal menjual hanya $60 \mathrm{Kg}$ per sayuran. Sedangkan untuk keperluan industri besar seperti saos dan makanan, biasanya dibutuhkan sayuran seperti tomat hingga 2-3 ton.

\section{Analisis Nilai Tambah Rantai Pasar Komoditas Pertanian}

Dalam analisis nilai tambah ini akan dijelaskan aspek-aspek yang terkait dengan nilai tambah yang diperoleh dari tiap pelaku rantai pasar. Analisis rantai pasar komoditas pertanian, didalamnya terdapat analisis harga dan penambahan nilai dari urutan kegiatan yang lengkap mulai dari produsen hingga proses akhir sampai ke konsumen (Tallec dan Bockel, 2005:4). Untuk nilai tambah pelaku sayuran, pelaku yang memperoleh nilai tambah paling besar adalah petani yaitu $\mathrm{Rp} \mathrm{3,044/Kg}$ sayuran. Pendapatan petani sedang bagus karena harga sayuran sedang bagus dan memberikan keuntungan yang cukup besar. Sedangkan untuk nilai tambah terkecil adalah pelaku pedagang/pengumpul desa dan pedagang pengumpul yang memiliki nilai tambah yang tidak terlalu besar yaitu ratarata Rp 500 per sayuran dikarenakan lokasi mereka yang sangat dekat dengan sentra sayuran yaitu di Kopeng, Kecamatan Getasan dan Kec. Ngablak, Kabupetan Magelang. Sehingga harga di sentra sayuran tersebut sangat bersaing untuk harga yang paling murah. Untuk nilai tambah sayuran dapat dilihat pada gambar di bawah ini. 


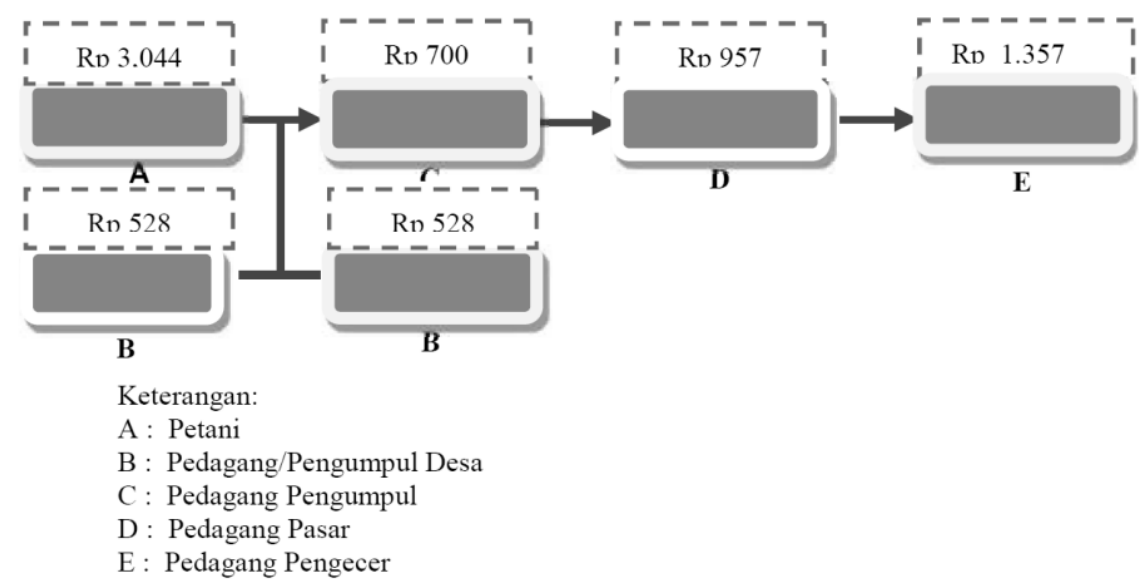

\section{Gambar 9. Nilai Tambah Pelaku Rantai Pelaku Sayuran}

Sedangkan untuk nilai tambah komoditas buah di bagi menjadi 2, yaitu nilai tambah buah lokal dan buah impor. Untuk pelaku buah lokal memiliki nilai tambah yang lebih sedikit dibandingkan buah impor. Nilai tambah terbesar untuk buah lokal dimiliki oleh pelaku pedagang pengumpul Pasar Johar dengan nilai tambah rata-rata $\mathrm{Rp} 1.250 / \mathrm{Kg}$. Hal ini dikarenakan terdapat dua jenis pedagang pengumpul di Pasar Johar, maka untuk jenis pedagang grosir seperti jeruk dan apel malang mendapatkan keuntungan yang hanya $7 \%$ dari semua hasil penjualan. Sehingga nilai tambah yang ditetapkan pedagang pengumpul cukup besar agar mendapatkan keuntungan lebih besar. Sedangkan untuk pedagang pasar mendapatkan nilai tambah paling kecil diantara pelaku lainnya yaitu sebesar Rp 675/Kg. Untuk nilai tambah buah lokal dapat dilihat pada gambar di bawah ini.

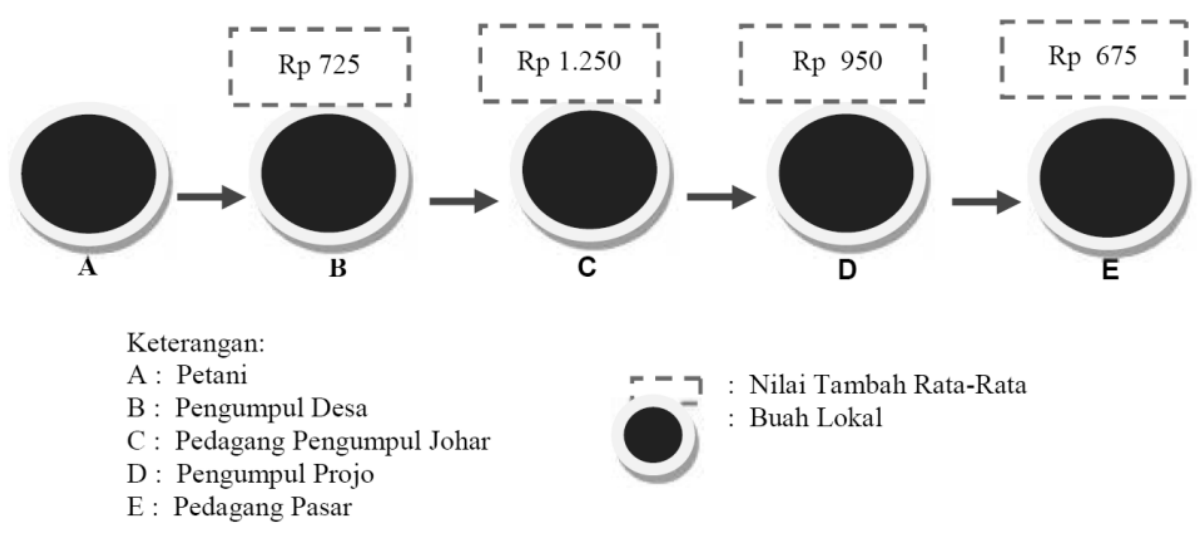

\section{Gambar 10. Nilai Tambah Pelaku Rantai Pelaku Buah Lokal}

Untuk buah impor yang memiliki nama dan kualitas luar yang cukup baik, pedagang pengumpul dan pedagang pasar mendapatkan nilai tambah yang cukup tinggi yaitu nilai tambah rata-rata Rp 3.600 untuk pengumpul Projo dan Rp 2.000 untuk pedagang pasar. Hal ini juga berlaku bagi pedagang pengumpul Johar yang mendapatkan nilai tambah terkecil yaitu Rp500/Kg. Nilai tambah ini juga disebabkan persaingan harga buah impor yang ketat di Semarang. 
Analisis Dampak Rantai Pasar Terhadap Kegiatan Perdagangan Komoditas Pertanian Pasar Projo

Dari uraian-uraian di atas dapat ditarik dampak rantai pasar dengan kegiatan perdagangan komoditas pertanian di Pasar Projo yaitu terfasilitasinya pedagang lokal untuk berjualan di Pasar Projo. Artinya dengan makin ramainya transaksi komoditas sayur dan buah di Pasar Projo memberi dampak tersendiri bagi masyarakat Ambarawa khususnya pedagang lokal untuk berjualan komoditas pertanian. Hal ini dapat dilihat dari data dominasi pedagang lokal sebanyak $81 \%$ dari semua pedagang komoditas pertanian. Dalam rantai terlihat bahwa pelaku nonlokal terdapat di dekat sentra pertanian, sedangkan dalam wilayah pemasaran didominasi oleh pelaku lokal.

Aktivitas aliran pada rantai pasar juga berdampak pada nilai tambah yang diterima pedagang lokal di Pasar Projo. Ternyata pedagang lokal di Pasar Projo mendapat keuntungan cukup besar dari hasil perdagangan komoditas pertanian ini. Keuntungan terbesar pedagang lokal adalah pengumpul buah impor yang mendapatkan nilai tambah sebesar Rp3,666 per Kg. Kemudian pedagang pasar buah impor juga mendapatkan nilai tambah cukup besar yaitu Rp 2000 per Kg. Untuk komoditas sayuran, pedagang pengecer sayuran dengan nilai tambah $\mathrm{Rp} \mathrm{1,357/Kg}$. Setelah pedagang pengecer, pedagang pasar sayuran juga mendapatkan nilai tambah cukup besar yaitu sebesar Rp 957/Kg sayuran. Dari beberapa pelaku tersebut, dapat disimpulkan bahwa pelaku lokal mendapatkan nilai tambah cukup besar dari kegiatan perdagangan komoditas pertanian di Pasar Projo. Hal ini dikarenakan jika dibandingkan pelaku lain, pelaku lokal ternyata mendapatkan nilai tambah yang cukup besar dibandingkan pedagang lain.

\section{Kesimpulan}

Dalam rantai pelaku komoditas sayuran dan buah di Pasar Projo memiliki struktur yang sama walaupun berbeda pelaku. Struktur tersebut yaitu adanya petani, perantara, pedagang pasar, dan konsumen. Pada rantai pelaku komoditas sayuran terdapat petani, pedagang/pengumpul desa, pedagang pengumpul, pedagang pasar, pedagang pengecer, pelaku industri kecil, dan konsumen. Sedangkan untuk pelaku rantai komoditas buah lebih panjang dibandingkan rantai pelaku komoditas sayuran. Hal ini disebabkan oleh rantai pelaku buah merupakan penggabungan antara pelaku buah lokal dan buah impor, selain itu komoditas buah juga banyak yang jauh dari wilayah pemasaran, yaitu berada di Jawa Timur dan luar negeri.

Pada dasarnya komoditas sayuran dan buah yang dipasarkan di Pasar Projo merupakan komoditas nonlokal. Asal komoditas sayuran yang dijual di Pasar Projo berasal dari Kecamatan Getasan dan Kecamatan Ngablak. Sedangkan untuk aliran antar pasar terjadi antara Pasar STA Jetis ke Pasar Projo, aliran ini berupa sayuran yang dibeli pedagang pasar Projo dari pedagang STA Jetis. Untuk asal komoditas buah juga didominasi oleh komoditas nonlokal dimana Jawa Timur sebagai sentra buah-buahan di Pasar Projo.

Wilayah pemasaran Pasar Projo yang mencapai wilayah Kabupaten Semarang, Kota Semarang, dan sekitarnya menggambarkan bahwa Pasar Projo sebagai pasar komoditas pertanian merupakan pasar regional yang wilayah pemasarannya wilayah lokal, wilayah sekitar dan wilayah regional. Walaupun dapat disebut pasar regional, tetapi pedagang pasar masih belum dapat melayani pelanggan dengan jumlah yang cukup besar karena kapasitas yang kecil.

Bentuk rantai pasar yang merupakan perubahan bentuk dasar sayuran dan buah menjadi olahan di Pasar Projo adalah pelaku industri kecil yang memakai bahan dasar sayuran dan buah untuk diolah menjadi bentuk lainnya, seperti warung makan, restoran, 
dan pkl yang mengolah menjadi makanan, sayur, jus, sup buah, dll. Sebagian besar pelaku ini merupakan pelaku rumah makan, pkl dan restoran.

Sedangkan untuk nilai tambah komoditas pertanian di Pasar Projo, Pelaku yang memperoleh nilai tambah paling besar adalah petani pengecer dengan nilai tambah ratarata Rp 3.344 per sayuran. Untuk nilai tambah buah lokal, nilai tambah terbesar untuk buah lokal dimiliki oleh pelaku pedagang pengumpul Pasar Johar dengan nilai tambah rata-rata Rp 1.250/Kg. Untuk buah impor yang memiliki nama dan kualitas luar yang cukup baik sehingga pedagang pengumpul dan pedagang pasar mendapatkan nilai tambah yang cukup tinggi yaitu nilai tambah rata-rata Rp 3.600 untuk pengumpul Projo dan Rp 2.000 untuk pedagang pasar.

\section{Rekomendasi}

Rekomendasi terkait rantai pasar komoditas pertanian di Pasar Projo adalah:

- Terkait fakta rantai pelaku yang lebih panjang akan mengakibatkan biaya dan harga menjadi lebih besar, sebaiknya pemerintah memposisikan petani tidak hanya menjadi produsen tetapi juga pemasaran agar rantai yang tejadi tidak menjadi panjang dan keterlibatan pengumpul dapat diperkecil.

- Terkait harga komoditas buah impor yang bersaing ketat dengan buah lokal, sebaiknya pemarintah lebih memproteksi petani buah lokal dan meningkatkan kualitas buah lokal dengan subsidi dan bantuan lainnya.

- Penurunan pendapatan pertanian menyebabkan komoditas nonlockal banyak beredar di Pasar Projo. Pengembangan pertanian di Ambarawa tetap ditingkatkan melalui komoditas pertanian yang berpotensi di Ambarawa seperti kangkung, sawi, dan jagung

- Dengan terfasilitasinya pedagang lokal di Pasar Projo, maka dibutuhkan penataan dan penambahan kapasitas pasar karena kapasitas pedagang melebihi kapasitas pasar khususnya pasar pagi, sebaiknya pengelola pasar lebih menfokuskan pada jumlah pedagang yang melebihi kapasitas pasar agar konsumen dapat lebih nyaman dalam berbelanja sayuran dan melakukan penataan pedagang sayuran agar lebih teratur.

\section{Daftar Pustaka}

Ahmadin. 1993. Kebijaksanaan Pemda DKI Jakarta dalam Menghadapi Fenomena Wilayah Mega Urban. Jurnal Perencanaan Wilayah dan Kota, Edisi Khusus Oktober.

Andini, Isti. 2006. "Sistem Perkotaan Pada Koridor Semarang - Surakarta”. Tugas Akhir tidak diterbitkan, Program Studi Perencanaan Wilayah dan Kota, Fakultas Teknik Universitas Diponegoro, Semarang.

Belshaw, Cyril S. 1981. Tukar Menukar Tradisional dan Pasar Modern. Jakarta: PT Gramedia.

Daldjoeni, N .1992. Geografi Baru : Organisasi Keruangan Dalam Teori dan Praktek. Bandung : Penerbit Alumni.

Djakapermana, Ruchyat Deni. 2010. Pengembangan Wilayah Melalui Pendekatan Kesisteman. Bogor: IPB Press.

Ferris, S., Kaganzi, E., Best, R., Ostertag, C., Lundy, M., T. Wandschneider, T., 2006. A market Facilitator's guide to participatory agroenterprise development. Centro Internacional de Agricultura Tropical (CIAT), Cali, Colombia

Kaplinsky, Raphael dan Mike Morris. 2000. A Handbook for Value Chain Research. IDRC.

Lundy, Mark et al. 2004. Increasing the Competitiveness Of Market Chains For Smallholder Producers. CIAT

Murtolo, Sudarmo Ali. 1995. "Dampak Pengembangan Ekonomi (Pasar) Terhadap Kehidupan Sosial Budaya Masayarakat Daerah Istimewa Yogyakarta (Studi Kasus, Pertanian Salak Pondoh Desa Bangunkerto)". DIY: Depatemen Pendidikan dan Kebudayaan. 


\section{Rantai Pasar Komoditas Pertanian dan Dampaknya Terhadap Kegiatan Perdagangan Komoditas Pertanian}

Parnwell, Mike. 1993. Population Movement and the Third World. London : Rotledge.

Purboyo, Heru H. P. 1992. Pergeseran Sistem Kota-kota di Indonesia (Dari Sentralisasi ke Desentralisasi). Departemen Permukiman dan Pengembangan Wilayah Direktorat Jenderal Penataan Ruang dan Pengembangan Wilayah[Homepage of NUDS2][Online]. Available at http//:geocities.com/nuds2/artikel/1html

Raco, J.R. 2010. Metode Penelitian Kualitatif. Jakarta: PT Gramedia Widiasarana Indonesia.

Rondinelli, Dennis A. 1983. Applied Method of Regional Analysis. Colorado: Westview Press.

Soegijoko, Budhy T. 2005. 'Keterkaitan Antarkota dalam Suatu Sistem Perkotaan' dalam Soegijoko, dkk (eds). Pembangunan Kota Indonesia dalam Abad 21. Jakarta: Lembaga Penerbit FEUI.

Stanton, William J dan Y lamarto. 1984. Prinsip Pemasaran (Edisi Ketujuh Jilid 1). Jakarta: Erlangga 